\title{
Technical Development Report
}

\section{エンコーダレス位置制御ドライブの開発}

技術開発レポート

1. はじめに

サーボモータドライブで位置制御を行う場合，エンコー ダやレゾルバなどの位置センサが用いられている。今回, 高調波重畳技術と IPM モータ (Interior Permanent Magnet Motor 永久磁石内蔵型モータ）との組合わせにより，サーボ ほどの位置制御精度は不要だが，簡単な位置制御を行いた いという用途向けに，エンコーダレス位置制御ドライブ C1000を開発したので紹介する。

(位置制御精度 : モータの電気角換算で \pm 10 度以下)

2. エンコーダレスの位置制御原理

エンコーダレスで位置制御を行うためには，モータの磁 極位置を正確に推定する必要がある。モータの磁極推定方 法には，誘起電圧を利用する方法やインピーダンスあるい はインダクタンスの磁極位置依存性(突極性)を利用する方 法がある。誘起電圧を利用する方法では，誘起電圧の振幅 が小さくなる低速域での磁極位置推定が難しい。今回，開 発した技術は，誘起電圧が無い停止時に，運転周波数とは 異なる高周波数電圧信号を出力電圧に重畳し，この結果流 れる高周波電流から磁極位置を検出し，誘起電圧の振幅か ら磁極位置推定可能な速度では，オブザーバで磁極位置を 推定している。重畳する高周波電圧信号の周波数は，運転 周波数とは無関係に設定できるので，運転に影響を与えず に，停止時でも磁極検出可能である。

以後，高周波重畳による磁極検出のアルゴリズムについ て簡単に説明する。IPM モータでは，突極比が大きい為， 図 1 のように磁極位置 $\theta \mathrm{r}$ に応じて, インピーダンス值 $\mathrm{Zh}$ が変化する。高周波電圧信号の周波数や振幅により，イン ピーダンス変化の振幅も異なる。

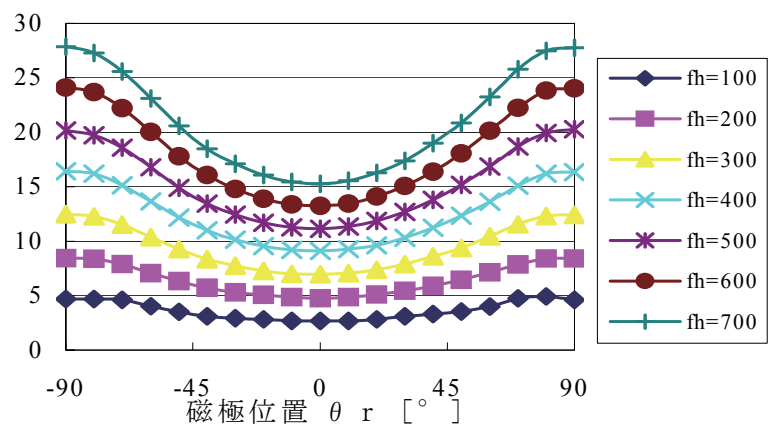

図 1 IPM モータのインピーダンス特性例 (重畳電圧振幅 $30[\mathrm{~V}]$, fh : 重盢周波数 $[\mathrm{Hz}]$ )
図 2 は, 高周波重畳方式による磁極位置推定方法の説明 図である。制御軸（ $\gamma$ 軸）に高周波電圧信号を重畳し，この 結果流れる高周波電流と高周波電圧信号とからインピーダ ンスを演算する。 $\gamma$ 軸から +45 度の位置のインピーダンス Z +とー45 度の位置のインピーダンス Z_を測定する。

$\gamma$ 軸とモータの磁極位置（ $\mathrm{d}$ 軸）が一致している場合， $Z_{+}$ $=\mathrm{Z}_{-}$となる為, $\mathrm{Z}_{+}$と $\mathrm{Z}_{-}$が一致するように， $\gamma$ 軸を $\Delta \theta$ だけ 調整することにより， $\gamma$ 軸とモータの磁極位置を一致させ， 磁極位置を推定している。この結果, モータの磁極位置の 正確な推定が可能となり, エンコーダレスでの位置制御を 実現した。

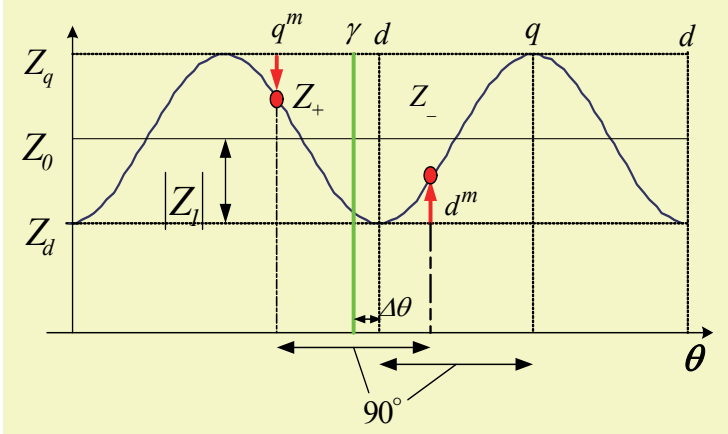

図 2 高周波重畳方式による磁極位置推定

3. エンコーダレスの位置制御のメリット

位置制御を行う場合，一般的には，エンコーダが必要で ある。しかしながら，エンコーダは精密機器の一つであり ながら，モータ軸に取り付けられており，振動や熱，塵埃， 湿気などの悪環境に設置されているため, エンコーダが故 障してしまう恐れがある。エンコーダが故障するとモータ の制御ができなくなり，機械停止を余儀なくされる。今回， 開発した位置制御ドライブは，モータの電気的特性より磁 極位置を検出して位置制御を行う為, エンコーダが不要で あり，環境の悪い場所でもエンコーダ故障の心配がなく装 置としての信頼性を大幅に向上できる。

\section{4.おおりに}

エンコーダレスの位置制御は，エンコーダ付と比較する と, 位置制御精度や応答性等の課題があるが，エンコーダ レスの位置制御技術は信頼性等の点でも非常に魅力があ る。今後, これらの課題を改善し, エンコーダレスの位置 制御の拡大，普及を狙う。

龍 英俊 (株式会社 安川電機)

(平成 22 年 6 月 1 日受付) 